\title{
Initial Growth of Yellow Passion Fruit Under Organic Fertilization
}

\author{
Francisco Hélio Alves de Andrade ${ }^{1}$, Anailson de Sousa Alves ${ }^{2}$, Maria Isabela Batista Clemente ${ }^{3}$, \\ Luana Ribeiro de Andrade ${ }^{2}$, Daivyd Silva de Oliveira ${ }^{4}$, Walter Esfrain Pereira ${ }^{5} \&$ Paulo Cássio Alves Linhares ${ }^{1}$ \\ ${ }^{1}$ Programa de Pós-Graduação em Agronomia (Fisiologia Vegetal), Universidade Federal de Lavras, Lavras, \\ MG, Brazil \\ ${ }^{2}$ Programa de Pós-Graduação em Agricultura e Ambiente, Universidade Estadual do Maranhão, MA, Brazil \\ ${ }^{3}$ Departamento de Gestão Ambiental, Universidade Estadual do Rio Grande do Norte, Mossoró, RN, Brazil \\ ${ }^{4}$ Programa de Pós-Graduação em Agronomia, Universidade Federal de Santa Maria, Santa Maria, RS, Brazil \\ ${ }^{5}$ Programa de Pós-Graduação em Ciência do Solo, Universidade Federal da Paraíba, Areia, PB, Brazil \\ Correspondence: Francisco Hélio Alves de Andrade, Programa de Pós-Graduação em Agronomia (Fisiologia \\ Vegetal), Universidade Federal de Lavras, Lavras, MG, Brazil. E-mail: helioalvesuepb@gmail.com
}

Received: May 14, 2018

doi:10.5539/jas.v10n9p191
Accepted: June 20, $2018 \quad$ Online Published: August 15, 2018

URL: https://doi.org/10.5539/jas.v10n9p191

\begin{abstract}
The production of yellow passion fruit seedlings is common among producers. Low cost techniques to maximize and reduce the cost of production with the application of cattle manure make the production of seedlings feasible. The objective of experiment was to evaluate different concentrations of cattle manure in substrate with and without liquid the biofertilizer in the production of yellow passion fruit seedlings. The experiment was carried out at the Universidade Estadual da Paraíba, Catolé do Rocha county, Paraíba state. The experimental design was completely randomized, in a $5 \times 2$ factorial scheme, with 5 repetitions end 3 plants per plot. The treatments consisted of five concentrations of cattle manure $(0,20,40,60$, and $80 \%$ of the substrate volume), without and with the biofertilizer $\left(10 \mathrm{~mL}\right.$ plant $\left.^{-1}\right)$. Sixty days after sowing, the following items were evaluated: plant height; number of leaves; root length; leaf area; leaf fresh mass; stem fresh mass; root fresh mass; aerial part fresh mass; total plant fresh mass; aerial part dry mass, and the Dickson quality index. The concentrations between 38 and $69 \%$ of composted cattle manure combined with the application of liquid biofertilizer increased the initial growth of yellow passion fruit plants, making its use feasible in the production of seedlings.
\end{abstract}

Keywords: Passiflora edulis Sims, organic input, quality of seedlings

\section{Introduction}

The genus Passiflora has about 400 species, 20 of which are restricted to Australia, China, India, Oceania and neighboring regions, and Southeast Asia, as well as Argentina, Chile, and the United States (Santos et al., 2012).

Academic studies mainly focus on the passion fruit culture (Passiflora edulis) due to its high commercial demand (Santos et al., 2012). One of its main species is the yellow passion fruit (Passiflora edulis Sims). In the agroindustrial chain, this fruit species plays an important role in the food, cosmetic, and medicinal areas, from its seedling formation stage to its fruit and by-products commercialization, generating employment and income (Costa et al., 2011).

According to Costa et al. (2011), the use of suitable techniques for seedling formation, such as microclimate improvement, container volumes, substrates, irrigation and nutrition are the paramount importance to promote healthy and vigorous plants for orchard formation. Additionally, substrates have an important role in the formation of nursery seedlings due to their importance in the promotion of the plants' growth and development (Cruz et al., 2008; Silva et al., 2010).

Several substrates mixtures are being used as alternatives to grow fruit species, such as goat manure, rice straw, compost, poultry manure, cattle manure, and worm castings, as well as different mixtures of these compounds. In this sense, studies with different substrates, doses of cattle manure and biofertilizers are necessary to improve the nutritional quality of the substrate and for physical quality purposes. The cattle manure generates improved substrate drainage and porosity, as well as increased water storage capacity, nutrient levels, and microbial population, assisting in the root development. Positive results were found by Canesin and Correa (2006) in 
papaya (scientific name), Silva et al. (2009) with mangabeira (Hancornia speciosa), and Costa et al. (2012) baruzeiro (Dipteryx alata) in a research whose purpose was to formulate alternative substrates with cattle manure to grow fruit seedlings.

Biofertilizers are defined in Normative Instruction No. 46 of October 6, 2011 (MAPA, 2012), as products that contain active components or biological agents capable of directly or indirectly act, entirely or partially, on cultivated plants, improving their production system performance; additionally they do not have substances that are prohibited by organic regulations.

One of the major problems in nursery seedlings production is related to the different alternative sources of substrates. Bovine manure is a low cost alternative in both the substrate formula and the source of organic biofertilizer. The use of different concentrations of bovine manure in the substrate formulation and absence of biofertilizer is a green bovine manure basis. In this sense, the objective of this work was to evaluate the effect of substrates with different amounts of bovine manure on the initial growth of yellow passion fruit with or without the biofertilizer liquid.

\section{Material and Methods}

The experiment was carried out between April and June of 2015, in the seedling production nursery of the Universidade Estadual da Paraíba (UEPB), Campus IV, Catolé do Rocha county, PB (6 $2^{\prime} 38^{\prime \prime} \mathrm{S}, 37^{\circ} 44^{\prime} 48^{\prime \prime} \mathrm{W}$, $275 \mathrm{~m}$ ). The nursery was covered with shading screen, allowing a luminosity level of $50 \%$ inside it. The experimental design was a completely randomized, $5 \times 2$ factorial, with five repetitions, corresponding to five proportions of cattle manure $(0,20,40,60$, and $80 \%$ of the substrate volume) in substrate with and without 10 $\mathrm{mL}$ plant $^{-1}$ of bovine biofertilizer. The first application was made 30 days after sowing (DAS), consisting of three applications of $10 \mathrm{~mL}$ of organic biofertilizer always applied at 8 hours per day. The propagation material used was the cultivar BRS GA1 launched in 2008 by Embrapa purchased in the local trade with a $95 \%$ purity level.

The sowing was done in polyethylene bags with a capacity of $1 \mathrm{dm}^{-3}$, where five seeds were sown per bag at a depth of one centimeter. The thinning of the seedlings was performed 24 days after sowing. The soil was classified as Eutrophic Floss neosol (Embrapa, 2011), whose analysis performed at a layer of $0-0.20 \mathrm{~m}^{-1}$ presented the following chemical attributes: $\mathrm{pH}$ in $\mathrm{H}_{2} \mathrm{O}=8.2 ; \mathrm{EC}=1.53 \mathrm{dS} \mathrm{m}^{-1} ; \mathrm{P}=3.27 \mathrm{mg} \mathrm{dm}^{-3} ; \mathrm{K}=0.26$ $\mathrm{cmol}_{\mathrm{c}} \mathrm{dm}^{-3} ; \mathrm{Ca}=5.09 \mathrm{cmol}_{\mathrm{c}} \mathrm{dm}^{-3} ; \mathrm{Mg}=1.66 \mathrm{cmol}_{\mathrm{c}} \mathrm{dm}^{-3} ; \mathrm{Al}=0.0 \mathrm{cmol}_{\mathrm{c}} \mathrm{dm}^{-3} ; \mathrm{Na}=0.26 \mathrm{cmol}_{\mathrm{c}} \mathrm{dm}^{-3}$ and $1.19 \%$ of organic matter. The cattle manure was acquired from the Bovine farming Sector of UEPB, Campus IV, Catolé do Rocha county, Paraíba state. The analysis presented the following chemical attributes: $\mathrm{N}=12.76 \mathrm{~g} \mathrm{~kg}$; $\mathrm{P}=$ $2.57 \mathrm{~g} \mathrm{~kg}^{-1} ; \mathrm{K}=16.79 \mathrm{~g} \mathrm{~kg}^{-1} ; \mathrm{Ca}=15.55 \mathrm{~g} \mathrm{~kg}^{-1} ; \mathrm{Mg}=4.02 \mathrm{~g} \mathrm{~kg}^{-1} ; \mathrm{Na}=5.59 \mathrm{~g} \mathrm{~kg}^{-1} ; \mathrm{Zn}=60 \mathrm{mg} \mathrm{kg}{ }^{-1} ; \mathrm{Fe}=8550$ $\mathrm{mg} \mathrm{kg}{ }^{-1} ; \mathrm{Mn}=325 \mathrm{mg} \mathrm{kg}^{-1}$; Organic matter $=396 \mathrm{~g} \mathrm{~kg}^{-1}$; Organic carbon $=229.7 \mathrm{~g} \mathrm{~kg}^{-1}$ and C/N ratio $18: 1$.

The material used to produce the bovine biofertilizer consisted of $70 \mathrm{~kg}$ of lactating cow green manure, $120 \mathrm{~L}$ of water, $4 \mathrm{~kg}$ of rock meal (MB4), $5 \mathrm{~kg}$ of vegetables (beans), $3 \mathrm{~kg}$ of wood ash, $5 \mathrm{~L}$ of milk and $5 \mathrm{~kg}$ of sugar to accelerate the metabolism of anaerobic bacteria for 35 days (Santos, 1992). The chemical composition of the bovine biofertilizer was analyzed through the dry matter at the Soil Fertility Laboratory (LFS) of theUniversidade Federal de Pernambuco, Pernambuco State, presenting the following results: $\mathrm{pH}^{\mathrm{H}} \mathrm{H}_{2} \mathrm{O}=5.25$; $\mathrm{EC}=7.1 \mathrm{dS} \mathrm{m}^{-1} ; \mathrm{N}=0.8 \% ; \mathrm{P}=403.4 \mathrm{mg} \mathrm{dm}^{-3} ; \mathrm{K}=1.78 \mathrm{cmol}^{-1} ; \mathrm{Mg}=6.0 \mathrm{cmol}_{\mathrm{c}} \mathrm{L}^{-1}$ and $\mathrm{Ca}=5.4 \mathrm{cmol}_{\mathrm{c}} \mathrm{L}^{-1}$.

They were irrigated twice a day, at 07:00 and 17:00 h, with the aid of a watering can with a capacity of 16 L. The irrigation water chemical analysis presented the following attributes: $\mathrm{pH}=8.13 ; \mathrm{EC}=0.99 \mathrm{dS} \mathrm{m}^{-1}: \mathrm{Ca}=1.305$ $\mathrm{mmol}_{\mathrm{c}} \mathrm{L}^{-1} ; \mathrm{Mg}=1.48 \mathrm{mmol}_{\mathrm{c}} \mathrm{L}^{-1} ; \mathrm{Na}=5.5 \mathrm{mmol}_{\mathrm{c}} \mathrm{L}^{-1} ; \mathrm{K}=0.49 \mathrm{mmol}_{\mathrm{c}} \mathrm{L}^{-1} ; \mathrm{CO}_{3}{ }^{2-}=0.44 \mathrm{mmol}_{\mathrm{c}} \mathrm{L}^{-1} ; \mathrm{HCO}_{3}{ }^{-}=3.67$ $\mathrm{mmol}_{\mathrm{c}} \mathrm{L}^{-1} ; \mathrm{Cl}=4.97 \mathrm{mmol}_{\mathrm{c}} \mathrm{L}^{-1}$; Dissolved sodium ratio $=3.29$; the water was classified as $\mathrm{C} 3$, according to Richards (1954).

The following items were evaluated after 60 of sowing: seedling height (SH); number of leaves (NL); root length (RL); leaf area (LA); leaf fresh mass (LFM); stem fresh mass (SFM); root fresh mass (RFM); aerial part fresh mass (APFM); total plant fresh mass (TPFM); aerial part dry mass (APDM), and the Dickson quality index (DQI).

The plant height was measured from the plant's base to its apex and the root length was measured from the base to the cap (final part of the root) with a ruler graduated, both in $\mathrm{cm}$. The leaf area was measured according to the methodology adopted by Benincasa (2003). The leaf fresh mass, stem fresh mass, root fresh fresh mass, aerial part fresh mass, and total plant fresh mass were measured through weight with the assistance of a digital scale with a precision of $0.1 \mathrm{mg}$. 
The area dry mass was obtained after drying it in an air-circulation oven at $65{ }^{\circ} \mathrm{C}$ for $72 \mathrm{~h}$ and then weighed in a digital scale. The Dickson Quality Index (DQI) was calculated according to Dickson et al. (1960), through the equation:

$$
\mathrm{DQI}=\frac{\mathrm{TDM}}{\frac{\mathrm{H}}{\mathrm{SD}}+\frac{\mathrm{RDM}}{\mathrm{APDM}}}
$$

Where, $\mathrm{TDM}=$ total dry mass; $\mathrm{H}=$ plant height; SD: stem diameter; $\mathrm{RDM}=$ root dry mass; $\mathrm{APDM}=$ aerial part dry mass.

The data were submitted for analysis of variance by the $\mathrm{F}$ test and regression up to $5 \%$ of significance, using the software SAS University Edition (Cody, 2015).

\section{Results and Discussion}

Table 1 shows the results of the analysis of variance, in which the biofertilizer influences effects only for SFM, RFM, APDM and DQI. Interaction between manure and biofertilizer influences all variables except RL. However, it was observed that the unfolding of RL in bovine manure depletion was with and without the biofertilizer (B0).

Table 1. Results of the analysis of variance of the variables: seedling height (SH); number of leaves (NL); root length (RL); leaf area (LA); leaf fresh mass (LFM); stem fresh mass (SFM); root fresh mass (RFM); aerial part fresh mass (APFM); total plant fresh mass (TPFM); aerial part dry mass (APDM), and the Dickson quality index (DQI). submitted to concentration of cattle manure and liquid biofertilizer in Passiflora edulis Sims

\begin{tabular}{|c|c|c|c|c|c|c|c|c|}
\hline \multirow{2}{*}{ VS } & \multirow{2}{*}{$\mathrm{DF}$} & \multicolumn{7}{|c|}{ Mean square } \\
\hline & & SH & NL & RL & & & LFM & SFM \\
\hline Manure (M) & 4 & $234.176^{* *}$ & $6.770^{* *}$ & $40.281^{* *}$ & & & $35.152^{* *}$ & $8.804^{* *}$ \\
\hline Biofertilizer(B) & 1 & $5.557^{\mathrm{ns}}$ & $0.080^{\mathrm{ns}}$ & $9.768^{\mathrm{ns}}$ & & & $0.272^{\mathrm{ns}}$ & $0.123^{* *}$ \\
\hline $\mathrm{M} \times \mathrm{B}$ & 4 & $10.579^{* *}$ & $2.230^{* *}$ & $6.980^{\mathrm{ns}}$ & & $4^{* *}$ & $9.828^{* *}$ & $0.327^{* *}$ \\
\hline Residue & 40 & 2.124 & 0.530 & 3.456 & & & 0.591 & 0.019 \\
\hline $\mathrm{VC} \%$ & & 9.83 & 7.19 & 6.44 & & & 10.82 & 7.91 \\
\hline Mean & & 14.82 & 10.12 & 28.87 & & & 7.11 & 1.75 \\
\hline \multirow{2}{*}{ VS } & \multirow{2}{*}{$\mathrm{DF}$} & \multicolumn{7}{|c|}{ Mean square } \\
\hline & & RFM & APFM & \multicolumn{2}{|c|}{ TPFM } & \multicolumn{2}{|c|}{ APDM } & DQI \\
\hline Manure (M) & 4 & $9.995^{* *}$ & $72.58^{4^{* *}}$ & \multicolumn{2}{|c|}{$114.403^{* *}$} & \multicolumn{2}{|c|}{$2.527^{* *}$} & $0.155^{* *}$ \\
\hline Biofertilizer(B) & 1 & $0.036^{* *}$ & $0.761^{\mathrm{ns}}$ & \multicolumn{2}{|c|}{$1.131^{\mathrm{ns}}$} & \multicolumn{2}{|c|}{$0.45^{8^{* *}}$} & $0.083^{* *}$ \\
\hline $\mathrm{M} \times \mathrm{B}$ & 4 & $1.047^{* *}$ & $12.378^{* *}$ & \multicolumn{2}{|c|}{$15.288^{* *}$} & \multicolumn{2}{|c|}{$0.349^{* *}$} & $0.045^{* *}$ \\
\hline Residue & 40 & 0.003 & 0.544 & \multicolumn{2}{|c|}{0.556} & \multicolumn{2}{|c|}{0.004} & 0.003 \\
\hline $\mathrm{VC} \%$ & & 2.04 & 8.32 & \multicolumn{2}{|c|}{6.28} & \multicolumn{2}{|c|}{4.61} & 12.91 \\
\hline Mean & & 3.00 & 8.86 & \multicolumn{2}{|c|}{11.86} & \multicolumn{2}{|c|}{1.45} & 0.44 \\
\hline
\end{tabular}

Note. ${ }^{* *},{ }^{*}=$ Significant at 1 and $5 \%$ through the $\mathrm{F}$ test, respectively; and ${ }^{\mathrm{ns}}=$ not significant.

Variation of source (VS), degree of freedom (DF), variation of coefficient (VC).

The proportions of composted cattle manure influenced the plant height, with and without the biofertilizer (Figure 1A). The maximum efficiency of cattle manure was in the proportions of $39.43 \%$ and $36.96 \%$, respectively, which resulted in plant heights of 24.49 and $18.78 \mathrm{~cm}$. The addition of biofertilizer resulted in a height increase of $23.31 \%$ of the seedling.

The benefit of cattle manure, according to Oliveira et al. (2010), may be related to the fact that, in proper amounts, it can supply the plants' needs due to the elevation of available levels of N, P, and K, which achieved the greatest contents in the soil. 

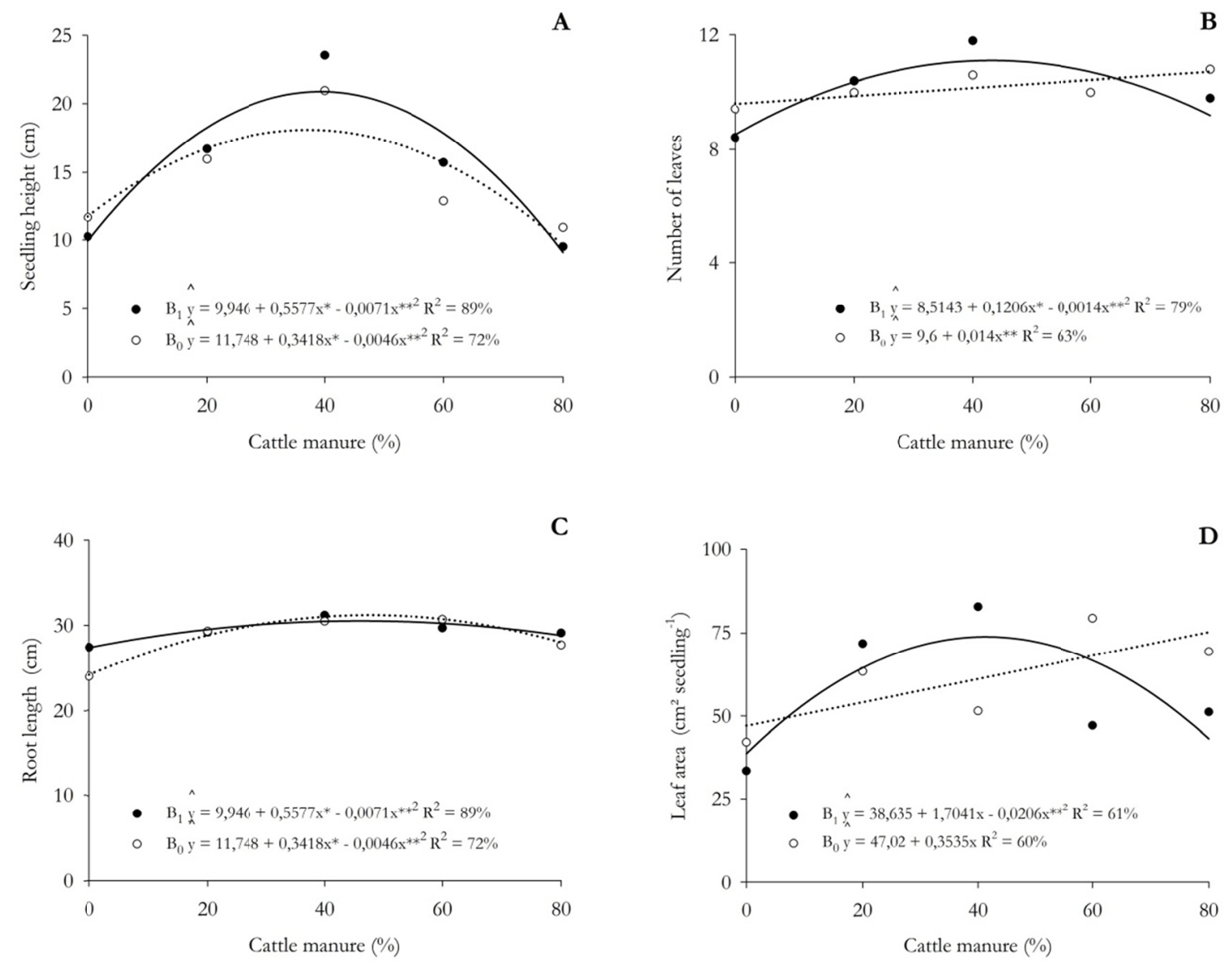

Figure 1. Seedling height (A), number of leaves (B), root length (C) and leaf area (D) according to the proportions of cattle manure with (B1) and without (B0) the biofertilizer in yellow passion fruit

The number of leaves increased proportionally with the amount of bovine manure to the estimated value of $42.86 \%$, providing 11 leaves with application of liquid biofertilizer (Figure 1B). In the absence of the biofertilizer, the highest number of 11 leaves was in the concentration of $80 \%$ bovine manure in the substrate.According to Silva et al. (2012), the efficiency of the biofertilizer may be associated with its easy assimilation, leading to an increase of water infiltration; additionally, organic matter helps to improve the condition and physical properties of the soil, considering the nutritional requirements of the crop.

The greatest root length increase was noticed in the cattle manure estimated proportions of $46.67 \%$ and $46.77 \%$ in substrate without and with biofertilizer bovine, respectively, resulting in 30.61 and $30.94 \mathrm{~cm}$ (Figure 1C). Silva et al. (2012) noticed that the interaction of cattle manure and biofertilizers via leaf promoted a greater average weight of tuberous roots of commercial yam (Dioscorea cayennensis Ham).

As for leaf area, a different behavior was noticed with and without the biofertilizer (Figure 1D). When the biofertilizer was used, a greater LA growth was noticed with the proportion of $41.26 \%$ of cattle manure, corresponding to $74.5 \mathrm{~cm}^{2}$. On the other hand, without the biofertilizer, it increased $75.02 \mathrm{~cm}^{2}$ at the maximum point of $80 \%$ of cattle manure. The use of the biofertilizer generated savings of $38.74 \%$ of cattle manure to induce a greater LA.

Leaf fresh mass presented a quadratic behavior for the increasing proportions of composted cattle manure, both without and with the biofertilizer (Figure 2A). However, the presence of bovine biofertilizer generated a higher LFM, especially with $42.18 \%$ of bovine manure composted provided a value of $9.6 \mathrm{~g}$ being superior to the derivatives of biofertilizer. Mesquita et al. (2012), evaluating the production of papaya plants according to increasing amounts of cattle manure, noticed an increasing linear response for aerial part dry mass production. 
A

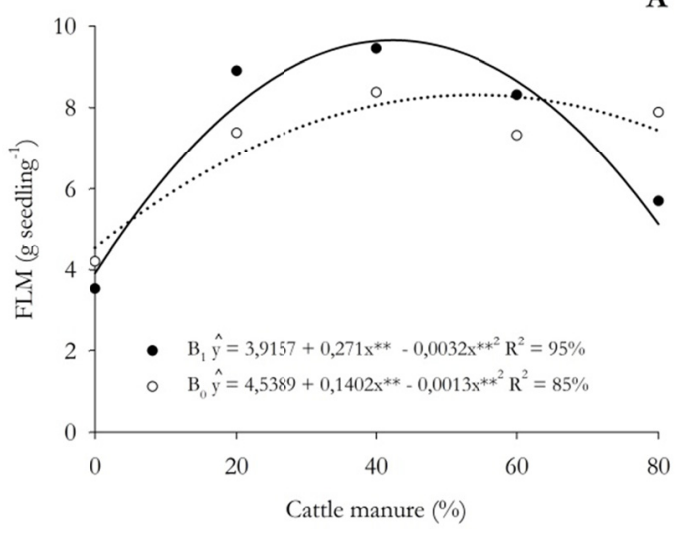

C

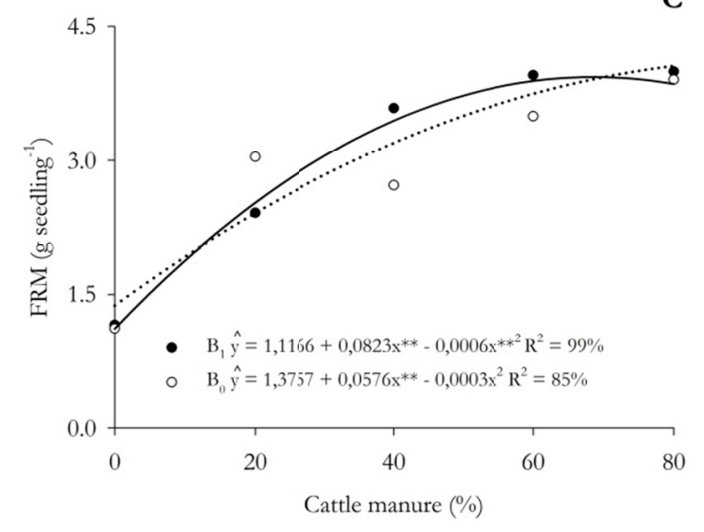

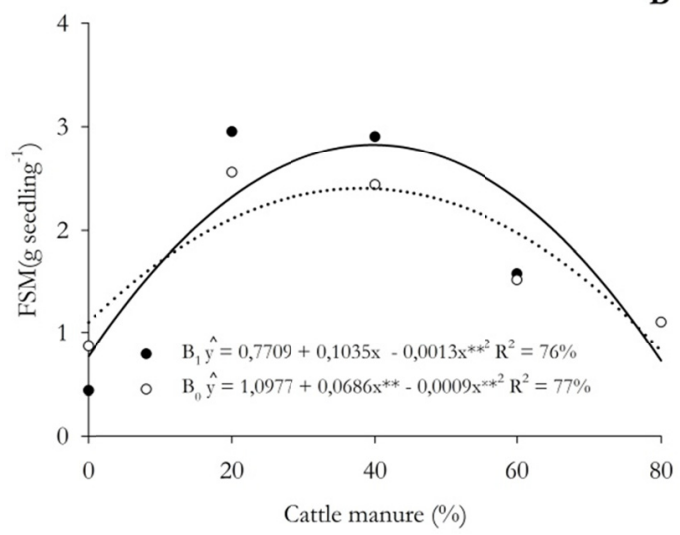

D

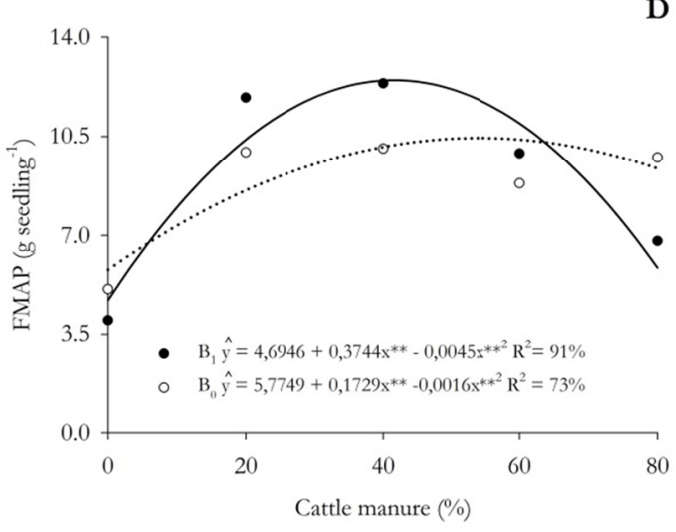

E

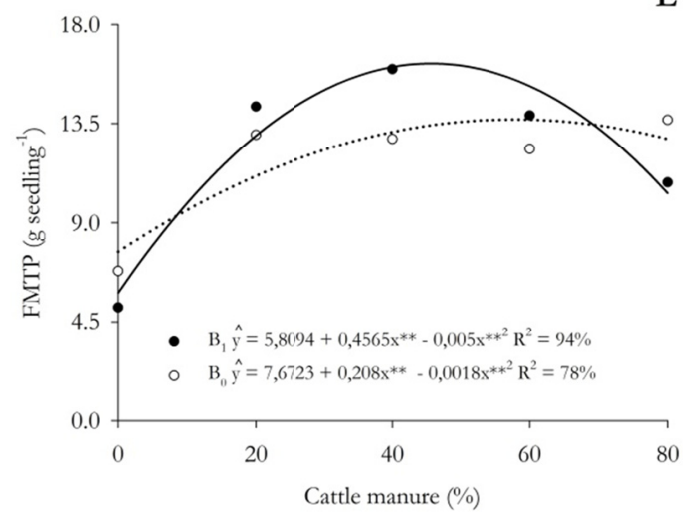

Figure 2. Leaf fresh mass (A), stem fresh mass (B), root fresh mass (C), aerial part fresh mass in yellow passion fruit seedlingsaccording to the increasing amount of cattle manure with $\left(B_{1}\right)$ and without $\left(B_{0}\right)$ the biofertilizer bovine

The fresh stem mass was adjusted to a quadratic polynomial model, with a maximum value of $2.85 \mathrm{~g}$ in the proportion of $38.46 \%$ of composted cattle manure with a liquid biofertilizer (Figure $2 \mathrm{~B}$ ). However, the root fresh mass behaved similarly when submitted to cattle manure concentrations and liquid biofertilizer applications, adjusting to the quadratic polynomial model, obtaining its value optimum in the concentration of $68.58 \%$ of the organic input applied with a liquid biofertilizer (Figure 2C).

The aerial part of the fresh mass presented quadratic behavior, where the highest values stimulated in the prasensa and absence of biofertilizer with $41.11 \%$ in the presence of manure and $53.12 \%$ of bovine manure 
respectively (Figure 2D). A similar behavior was noticed by Oliveira et al. (2013) in their study of the mean fruit mass with okra (scientific name) fertilized with cattle manure and fertilizers, in which the presence of biofertilizers at the optimum ratio of $27.58 \mathrm{t} \mathrm{ha}^{-1}$ resulted in a greater mean fruit mass. Oliveira et al. (2013) reported that the proportion of cattle manure with biofertilizers increased the mean fruit mass and the okra fruit commercial yield.

The concentration of $45 \%$ of cattle manure with the biofertilizer generated a greater TPFM $(2.15 \mathrm{~g})$ in comparison with the optimal proportion of cattle manure without the biofertilizer $13.75 \mathrm{~g}$ (Figure 2E). A similar effect was noticed by Diniz et al. (2013), in which the presence of biofertilizers generated greater results in root dry mass (RDM), aerial part dry mass (APDM), and total plant dry mass (TPDM) in the initial growth of neem.

For aerial part dry mass, the concentration of $41.66 \%$ of cattle manure without the biofertilizer resulted in $2.01 \mathrm{~g}$, whereas a $30 \%$ concentration of cattle manure with the biofertilizer resulted in $1.54 \mathrm{~g}$ (Figure 3A). It can also be noticed that the absence of the biofertilizer promoted a greater aerial part dry mass, in the equivalent amount of $23.38 \%$ in relation to the optimum concentration of cattle manure with the biofertilizer (Figure 3A). The total amount of cattle per animal is $0.6 \%$ of the population. The total area of the trees is $0.8 \%$. It can also be noticed that the absence of biofertilizer promoted to greater aerial part dry mass, in the equivalent amount of $23.38 \%$ in relation to the optimum concentration of cattle manure with the biofertilizer (Figure 3A). Oliveira et al. (2017) found that the increase of the doses of the biofertilizers promoted the growth of the lateral branches, reducing the pruning period, with greater expressiveness for the common biofertilizer, reaching the pruning point of the branches at 41 days, at the estimated dose of $8.6 \%$ of biofertilizer in yellow passion fruit plants.
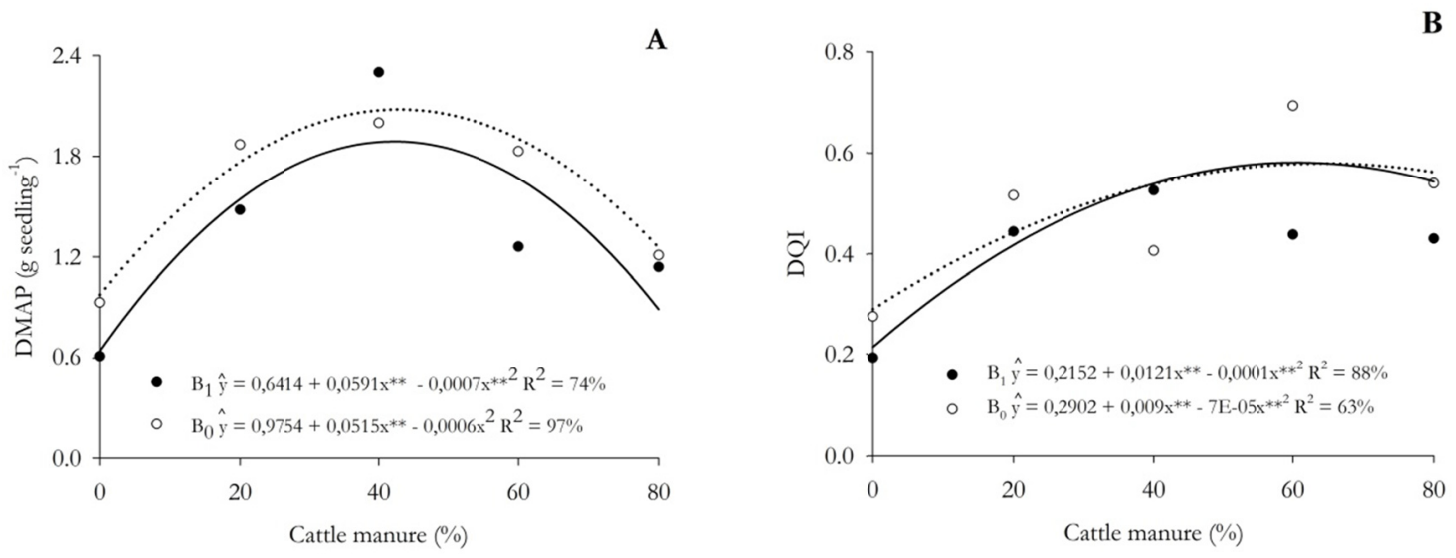

Figure 3. Aerial part dry mass (A) and the Dickson Quality Index (B) in yellow passion fruit seedlings according to the amounts of cattle manure with $\left(\mathrm{B}_{1}\right)$ and without $\left(\mathrm{B}_{0}\right)$ the biofertilizer

The quality of the seedlings measured by the Dickson Quality Index (DQI) was adjusted to the quadratic polynomial model, presenting the optimum concentrations of $60.5 \%$ and $64.28 \%$ of composted manure with DQI 0.57 indicators both with and without the biofertilizer, respectively. It is a good indicator of the seedlings' quality because its calculation considers the biomass balance and plant resistance, using several important parameters. The author recommends an index of 0.20 as a minimum value in DQI for suitable-for-transplant, high-quality seedlings. Guerra et al. (2017) found lower value in passion fruit seedlings that ranged from 0.12 to $0.51 \mathrm{DQI}$ by testing different substrates.

On the Table 2 is presents the correlation matrix between the variables evaluated in the experiment to verify the greatest correlations between the variables. However, all correlations were positive. Plant height has high correlations of $81 \%, 70 \%, 60 \%$, and $77 \%$ for stem fresh mass (SFM), aerial part fresh mass (APFM), total plant fresh mass (TPFM), and aerial part dry mass (APDM). As for the number of leaves, it has a great correlation of $68 \%, 70 \%, 70 \%$, and $65 \%$ with leaf fresh mass (LFM), aerial part fresh mass (APFM), total plant fresh mass (TPFM), aerial part dry mass (APDM), respectively. Leaf fresh mass presented correlations with the matrix of $70 \%, 61 \%, 97 \%, 97 \%, 68 \%$, and $62 \%$ with SFM, RFM, APFM, TPFM, APDM, and DQI, respectively.

Number of leaf and leaf fresh mass are directly linked with the plant's leaf area. However, the larger the leaf area is, more likely it will fixate $\mathrm{CO}_{2}$ through the plant's metabolism. Another important correlation to be noticed is 
the DQI with RFM, TPFM, and APDM, which is an index that indicates the seedlings' quality through dehydrated vegetable matter, because the greater the DQI is, the better the seedlings will be for plantation.

Table 2. Correlation matrix between the growth and biomass variables in yellow passion fruit seedlings

\begin{tabular}{llllllllllll}
\hline Variables & PH & NL & RL & SLA & LFM & SFM & RFM & APFM & TPFM & APDM & DQI \\
\hline PH & 1.00 & & & & & & & & & & \\
NL & 0.56 & 1.00 & & & & & & & & & \\
RL & 0.27 & 0.19 & 1.00 & & & & & & & & \\
SLA & 0.18 & 0.39 & 0.47 & 1.00 & & & & & & & \\
LFM & 0.58 & 0.68 & 0.23 & 0.44 & 1.00 & & & & & & \\
SFM & 0.81 & 0.57 & 0.19 & 0.31 & 0.70 & 1.00 & & & & & \\
RFM & 0.12 & 0.47 & 0.12 & 0.35 & 0.61 & 0.22 & 1.00 & & & & \\
APFM & 0.70 & 0.70 & 0.23 & 0.43 & 0.97 & 0.84 & 0.53 & 1.00 & & & \\
TPFM & 0.60 & 0.70 & 0.22 & 0.45 & 0.97 & 0.75 & 0.72 & 0.97 & 1.00 & & \\
APDM & 0.77 & 0.65 & 0.25 & 0.39 & 0.68 & 0.82 & 0.44 & 0.77 & 0.76 & 1.00 & \\
DQI & 0.12 & 0.45 & 0.10 & 0.49 & 0.62 & 0.39 & 0.70 & 0.59 & 0.68 & 0.66 & 1.00 \\
\hline & & & & & & & & & & & \\
\hline
\end{tabular}

\section{Conclusions}

The proportion of $38 \%$ to $69 \%$ of composted cattle manure in association with the application of the liquid biofertilizer increased the initial growth of yellow passion fruit plants, making its use feasible in the production of seedlings.

The proportion of $41.7 \%$ to $80 \%$ of composted cattle manure without the biofertilizer promoted greater values of RL, SLA, APDM, and DQI in Passiflora edulis Sims fflavicarpa Deg.

The proportion of $64 \%$ of bovine manure promotes better DQI, an indication that this dose is the best to produce quality seedlings.

\section{References}

Benincasa, M. M. P. (2003). Análise de crescimento de plantas: Noções básicas (2nd ed., p. 41). Jaboticabal, FUNEP.

Busato, J. G., Zandonadi, D. B., Sousa, I. M., Marinho, E. B., Dobbss, L. B., \& Mól, A. R. (2016). Efeito do extrato húmico solúvel em água e biofertilizante sobre o desenvolvimento de mudas de Callophyllum brasiliense. Pesquisa Florestal Brasileira, 36, 161-168. https://doi.org/10.4336/2016.pfb.36.86.1024

Canesin, R. C. F. S., \& Correa, L. S. (2006). Uso de esterco associado à adubação mineral na produção de mudas de mamoeiro (Carica papaya L.). Revista Brasileira de Fruticultura, 28, 481-486. https://doi.org/10.1590/ S0100-29452006000300031

Cody, R. (2015). Introdução à SAS University Edition (p. 49). Retrieved from https://support.sas.com/content/ dam/SAS/support/en/books/an-introduction-to-sas-universityedition/68380_excerpt.pdf

Costa, E., Oliveira, L. C., Espírito Santo, T. L., \& Leal, P. A. M. (2012). Production of baruzeiro seedling in different protected environments and substrates. Engenharia Agrícola, 32, 633-641. https://doi.org/10.1590/ S0100-69162012000400002

Costa, E., Santos, L. C. R., Carvalho, C., Leal, P. A. M., \& Gomes, V. A. (2011). Volumes de substratos comerciais, solo e composto orgânico afetando a formação de mudas de maracujazeiro-amarelo em diferentes ambientes de cultivo. Revista Ceres, 58, 216-222. https://doi.org/10.1590/S0034-737X20 11000200013

Cruz, M. C. M., Ramos, J. D., Oliveira, D. L., Marques, V. B., \& Hafle, O. M. (2008). Utilização de água residuária de suinocultura na produção de mudas de maracujazeiro-azedo cv Redondo Azedo. Revista Brasileira de Fruticultura, 30, 107-1112. https://doi.org/10.1590/S0100-29452008000400043

Dickson, A., Leaf, A. L., \& Hosner, J. F. (1960). Quality appraisal of white spruce and white pine seedling stock in nurseries. Forestry Chronicle, 36, 10-13. https://doi.org/10.5558/tfc36010-1 
Diniz, B. L. M. T., Cavalcante, L. F., Mesquita, F. O., Lima Neto, A. J., Nunes, J. C., \& Diniz Neto, M. A. (2013) Crescimento inicial e consumo hídrico de nim submetido ao estresse salino e biofertilizante bovino. Revista Brasileira de Ciências Agrárias, 8(3), 470-475. https://doi.org/10.5039/agraria.v8i3a2613

Guerra, M. S., Barbosa, M. S., Costa, E., \& Vieira, G. H. C. (2017). Recipiente biodegradável e substratos para mudas de maracujazeiro. Revista de Agricultura Neotropical, 4, 50-54. Retrieved from http://periodicosonline.uems.br/index.php/agrineo/article/view/1641/1555

Hartmann, H. T., Kester, D. E., Davies Junior, F. T., \& Geneve, R. L. (2010). Plant propagation: Principles and practices (p. 928). Prentice-Hall.

Malavolta, E., Gomes, F. P., \& Alcarde, J. C. (2002). Adubos e Adubações (p. 200). São Paulo: Nobel.

MAPA (Ministério da Agricultura, Pecuária e Abastecimento). (2012). Estabelece o Regulamento Técnico para os Sistemas Orgânicos de Produção Animal e Vegetal. Instrução Normativa MAPA nº 46 de 06/10/2011.

Mesquita, E. F., Chaves, L. H. G., Freitas, B. V., Silva, G. A., Sousa, M. V. R., \& Andrade, R. (2012). Produção de mudas de mamoeiro em função de substratos contendo esterco bovino e volumes de recipientes. Revista Brasileira de Ciências Agrárias, 7, 58-65. https://doi.org/10.5039/agraria.v7i1a1448

Oliveira, A. P., Oliveira, A. N., Silva, O. P. R., Pinheiro, S. M., \& Gomes Neto, A. D. (2013). rendimento do quiabo adubado com esterco bovino e biofertilizante. Semina: Ciências Agrárias, 34, 2629-2636. https://doi.org/10.5433/1679-0359.2013v34n6p2629

Oliveira, A. P., Santos, J. F., Cavalcante, L. F., Pereira, W. E., Santos, M. C. C. A., Oliveira, A. N. P., \& Silva, N. V. (2010). Yield of sweet potato fertilized with cattle manure and biofertilizer. Horticultura Brasileira, 28, 277-281. https://doi.org/10.1590/S0102-05362010000300006

Oliveira, F. I. F., Medeiros, W. J. F., Cavalcante, L. F., Cavalcante, I. H. L., Souto, A. G. L., \& Lima Neto, A. J. (2017). Crescimento e produção do maracujazeiro amarelo fertirrigado com esterco bovino líquido fermentado. Revista Agropecuária Técnica, 38, 191-199. https://doi.org/10.25066/agrotec.v38i4.34434

Santos, A. C. V. (1992). Biofertilizante líquido: O defensivo da natureza. Agropecuária Fluminense, 8 (2nd ed.). Ver. Niterói: EMATER-Rio.

Santos, J. L., Matsumoto, S. N., D’arêde, L. O., Luz, I. S., \& Viana, A. E. S. (2012). Propagação vegetativa de estacas de Passiflora cincinnata mast. em diferentes recipientes e substratos comerciais. Revista Brasleira de Fruticultura, 34, 581-588. https://doi.org/10.1590/S0100-29452012000200033

Silva, E. A., Maruyama, W. I., Mendonça. V., Francisco, M. G. S., Bardiviesso, D. M., \& Tosta, M. S. (2010). Composição de substratos e tamanho de recipientes na produção e qualidade das mudas de maracujazeiro 'azedo'. Ciência e Agrotecnologia, 34, 588-595. https://doi.org/10.1590/S1413-70542010000300009

Silva, E. A., Maruyama, W. I., Oliveira, A. C., \& Bardiviesso, D. M. (2009). Efeito de diferentes substratos na produção de mudas de mangabeira (Hancornia speciosa). Revista Brasileira de Fruticultura, 31, 925-929. https://doi.org/10.1590/S0100-29452009000300043

Silva, J. A., Oliveira, A. P., Alves, G. S., Cavalcante, L. F., Oliveira, A. N. P., \& Araújo, M. A. M. (2012). Rendimento do inhame adubado com esterco bovino e biofertilizante no solo e na folha. Revista Brasileira de Engenharia Agrícola e Ambiental, 16, 253-257. https://doi.org/10.1590/S1415-43662012000300003

Sousa, G. G., Marinho, A. B., Albuquerque, A. H. P., Viana, T. V. A., \& Azevedo, B. M. (2012). Crescimento inicial do milho sob diferentes concentrações de biofertilizante bovino irrigado com águas salinas. Revista Ciência Agronômica, 43, 237-245. https://doi.org/10.1590/S1806-66902012000200005

Wanderley, M. G. L., Shepherd, G. J., Giulietti, A. M., \& Melhem, T. S. (2003). Flora fanerogâmica do Estado de São Paulo (Vol. 3, pp. 248-274). São Paulo: RiMa/FAPESP.

\section{Copyrights}

Copyright for this article is retained by the author (s), with first publication rights granted to the journal.

This is an open-access article distributed under the terms and conditions of the Creative Commons Attribution license (http://creativecommons.org/licenses/by/4.0/). 